\title{
Human Development and Economic Uncertainties: Exploring Another Dimension of Development
}

\author{
Jamshed Y. Uppal ${ }^{*}$ and Syeda Rabab Mudakkar**
}

\begin{abstract}
This study makes the case that economic uncertainties-i.e., the extent to which economies face systemic uncertainties-need to be considered another dimension of human development because they render development vulnerable, diminish social welfare, and constrain human capabilities. We propose a methodology for adjusting the human development index (HDI) for economic uncertainties, using the time variability of income changes as a proxy. We construct an adjusted index associated with the income component for the 2011 HDI. Our analysis indicates that such an index contains additional information. The percentage loss in the income component of the HDI seems to reflect the variability in economic indicators arising from the political and economic tribulations experienced by each country. In Pakistan's case, the results of a timeseries analysis of the percentage loss from the uncertainty adjustment appear to closely trace the country's political and economic upheavals.
\end{abstract}

Keywords: Human development index, capabilities, human development, economic growth, economic vulnerability, uncertainty, risk.

JEL classification: D63, I32, I38.

\section{Introduction}

The United Nations Development Programme (UNDP)'s human development index (HDI) has been instrumental in focusing on the nexus between human development and economic growth. The index's simplicity in characterizing development as a composite of achievements in health, education, and income has made it a particularly useful tool for advocacy purposes and in de-emphasizing a growth-centric view of development.

The HDI has undergone many revisions since its inception in 1990. UNDP (2010) revised its indicators and functional form, but retained the index's three-dimensional structure. To address a major criticism that the

\footnotetext{
${ }^{*}$ Associate Professor of Finance, Catholic University of America, Washington, DC.

** Assistant Professor of Statistics, Lahore School of Economics, Pakistan.
} 
HDI neglected within-country inequality, three additional indices were introduced: the inequality-adjusted HDI, the gender inequality index, and the multidimensional poverty index. According to Klugman, Rodríguez, and Choi (2011): "The 2010 HDR made a significant move away from the idea that the ideal measure of human development must cover only the three core dimensions." It is in this spirit that we explore a new dimension of human development in this paper.

One dimension that has not received much attention is the extent to which populations face economic uncertainties, rendering development vulnerable. These uncertainties arise from a wide range of risk factors, e.g., natural disasters, systemic political and market failures, external economic shocks, and adverse technological and market changes. The overall impact of economic uncertainties is to diminish human capabilities in the sense originally conceived of by Amartya Sen-"development as capability expansion" (Sen, 1985, 1990). The 2010 Human Development Report (HDR) raises the issue of economic vulnerabilities, noting that, "countries and people are vulnerable when their human development is threatened by various risks," but promises to address it in the following HDR (UNDP, 2010). The 2011 HDR, however, takes it up as an issue of development sustainability in the broader environmental, economic, and social context (UNDP, 2011).

We argue that economic uncertainties need to be explicitly considered as another dimension (negative) of human capabilities, and propose an uncertainty-adjusted HDI (U-HDI). Our methodology for constructing such an index takes the time variability of income changes as a proxy for economic vulnerability. This study presents the results of an exploratory exercise in constructing such an index across countries. We also present a detailed analysis for Pakistan in the context of the uncertainties associated with the country's political and economic environment over time.

\section{Background}

Since its introduction in 1990, the HDI has become a "yardstick of wellbeing" in discussions on development issues. Its basic message, that development is much more than income growth, has forced policymakers and development economists alike to move away from "growth-centric" thinking and focus on other dimensions of development such as health and education. Its prime movers, the late Pakistani economist Mahbub ul Haq 
and Nobel laureate Amartya Sen, had sought an alternative to per capita income as the standard measure of development. ${ }^{1}$

The resulting HDI aggregated three basic dimensions into a composite index, motivated by the view that, "Human development is a process of enlarging people's choices. [...] The three essential ones are for people to lead a long and healthy life, to acquire knowledge and to have access to resources needed for a decent standard of living" (UNDP, 1990, p. 10). The index's simplicity in characterizing development as a composite of achievements in health, education, and income has made it a particularly useful tool for advocacy purposes and encapsulating a comprehensive view of development.

Until 2010, the HDI was defined as a simple arithmetic average of its sub-indices-health, education, and income-based on normalized indicators of achievements in each of these dimensions. Life expectancy and GDP per capita were used as proxies for health and living standards, respectively, while the literacy ratio and gross enrolment ratio were used to measure education. The sub-indices were then normalized using given upper and lower bounds. The HDI has undergone many revisions since its inception in 1990, and the choice of indicators and definition of sub-indices had varied over time. However, it has retained its basic original structure.

While the HDI is accepted as a measure of development, it has also invited much criticism in two broad categories: (i) its choice of development dimensions, and (ii) its functional form. Critics point out that the HDI excludes other obvious dimensions of wellbeing, such as equity, political freedoms, human rights, sustainability, and happiness. For example, Sagar and Najam (1998) note that the HDI "ignores the environmental dimensions of development, especially the relationships between the performance of countries on the environmental and human development dimensions." The HDI is also criticized for not capturing all of people's freedoms and opportunities, for example, Nussbaum (2000) would include personal, social, and political freedoms in her list of ten basic capabilities, and Dasgupta and Weale (1992) would include political and civil liberties.

Partly in response to the criticism regarding the narrowness of the HDI, some studies have advocated multidimensional measures. For example, Alkire and Foster (2011) discuss the strengths and limitations of

\footnotetext{
1 "Any measure that values a gun several hundred times more than a bottle of milk is bound to raise serious questions about its relevance for human progress" (Haq, 1995).
} 
multidimensional poverty measures and provide a "dual cutoff" identification approach that views poverty as the state of being multiply deprived. An earlier study by Alkire (2002) discusses the usefulness and limitations of various dimensions of human development in relation to Sen's capability approach. She provides a survey of other major lists of dimensions developed by various scholars.

In response to various criticisms, the HDI has been revised many times. In the most recently revised HDI (UNDP, 2010), ${ }^{2}$ three of the four variables that constitute the index were altered-GDP per capita was replaced by gross national income (GNI) per capita (both valued in terms of US dollar-based purchasing power parity), and literacy and gross enrolment were replaced by mean years of schooling and expected years of schooling, respectively. The method of aggregation was changed from an arithmetic average to a geometric average, and the upper and lower bounds used to normalize the index were redefined, eliminating the practice of capping variables that exceeded the upper bounds. To address a major criticism that the HDI neglected within-country inequality, three additional indices were introduced: (i) the inequality-adjusted HDI, (ii) the gender inequality index, and (iii) the multidimensional poverty index.

The 2010 HDI, however, retains its three-dimensional structure and new dimensions were not introduced on several grounds. Among others, one reason appears to be a continued focus on opportunity freedomsfreedoms that give us greater opportunity to achieve the things we valueas opposed to process freedoms, i.e., those that ensure that the process through which things happen is fair, based on Sen's (2002) distinction. However, the 2010 HDR makes a strong case for the consideration of several process freedoms in the discussion on human development, and for "broader dimensions" of human development: empowerment, sustainability and equity. One of the report's key contentions is that the measurement of human development should be expanded beyond the core dimensions.

The evolution of the HDI shows that the measurement of human development is an ongoing challenge. According to Klugman et al. (2011): "The 2010 HDR made a significant move away from the idea that the ideal measure of human development must cover only the three core dimensions, and presented three new measures that take into account different aspects of the distribution of human development." The report

\footnotetext{
${ }^{2}$ Klugman et al. (2011) and Lustig (2011) explain in detail the rationale for the new HDI, while Ravallion (2010) offers a critical view.
} 
also published on its website a feature that allows users to "build your own development index."

For Klugman et al. (2011), the position taken by the 2010 HDR constitutes a significant departure from the traditional vision of the index in which the report's authors would set the weights objectively; instead, the weights and measures used are subject to open public debate. This premise, accordingly, informs our study.

\section{Inequality-Adjusted HDI}

Of particular interest with respect to our study are the innovative inequality-adjusted indices that go beyond the HDI, and are designed to address the key dimensions of inequality and deprivation. Although the HDR has always recognized that inequality in human development is a serious issue, an inequality-based index could not be operationalized earlier due to the nonavailability of data. The inequality-adjusted HDI (IHDI) is a measure of the level of human development of people in a society that accounts for inequality in health, education, and income, and is directly comparable to the HDI across countries. ${ }^{3}$

There are three main steps to computing the IHDI. First, inequality in the underlying distributions is measured. The IHDI builds on the family of inequality measures proposed by Atkinson (1970). In case the aversion parameter $\varepsilon$ equal to 1 , Atkinson's inequality measure is $A=1-\gamma / \mu$, where $\gamma$ is the geometric mean and $\mu$ the arithmetic mean of the distribution. This can be written as:

$$
A_{x}=1-\frac{\sqrt[n]{X_{1} \cdots X_{n}}}{\bar{X}}
$$

where $\left\{X_{1}, \ldots, X_{n}\right\}$ denotes the underlying distribution for the variable of interest. $A_{x}$ is obtained for each HDI dimension (life expectancy, years of schooling, and disposable income or consumption per capita) from household survey data and life tables.

The second step is to adjust the mean achievement in a dimension, $X$, for inequality as follows:

$$
\bar{X}^{*}=\bar{X}\left(1-A_{x}\right)=\sqrt[n]{X_{1} \cdots X_{n}}
$$

\footnotetext{
${ }^{3}$ Alkire and Foster (2011) and Kovacevic (2011) provide details on measuring inequality in the distribution of the HDI indicators.
} 
Thus $X^{*}$, the geometric mean of the distribution, is used to lower the mean according to the degree of inequality in the distribution. The use of the geometric mean emphasizes the lower end of the distribution. The inequality-adjusted dimension indices, $I_{I X}$, are obtained from the HDI dimension indices by multiplying them by $\left(1-A_{x}\right)$, where $A_{x}$ is the corresponding Atkinson measure:

$$
I_{1 x}=\left(1-A_{x}\right) \cdot I_{X}
$$

The IHDI is then calculated as:

$$
I H D I=\sqrt[3]{\left(1-A_{\text {Life }}\right) \cdot\left(1-A_{\text {Education }}\right) \cdot\left(1-A_{\text {Income }}\right)} \cdot H D I .
$$

\section{Economic Uncertainties, Vulnerability, and Resilience}

A development dimension that has not received much attention is the extent to which economies face economic uncertainties. These uncertainties can arise from a wide range of risk factors, e.g., natural disasters, systemic political and market failures, external economic shocks, and adverse technological and market changes. Such uncertainties put people's wealth and wellbeing at risk, and render human development vulnerable. The overall impact of economic uncertainties is to diminish human capabilities in the sense conceived of by Sen $(1985,1990)$.

The concepts of economic vulnerability and resilience, first explored by Briguglio (1995, 2003), have existed in economics literature for some time. A number of empirical studies (see, for example, Briguglio, 2003; Crowards, 2000; Atkins, Mazzi, \& Easter, 2000) show that small states, particularly island states, tend to be economically more vulnerable than other countries. An economy's structural characteristics, e.g., a high degree of economic openness and export concentration, lead to higher exposure to exogenous shocks, which can magnify economic fluctuations and risks in economic growth. Cordina (2004a, 2004b) shows that higher variability in the economic growth rate can also adversely affect economic growth itself.

The term 'resilience' refers to the ability to recover quickly from the effect of an adverse shock to the economy. ${ }^{4}$ Briguglio (2003) observes that some small states are able to generate a relatively high GDP per capita despite their higher vulnerability to external economic shocks. He terms

\footnotetext{
${ }^{4}$ Merriam-Webster defines resilience as (i) the capability of a strained body to recover its size and shape after deformation caused especially by compressive stress, and (ii) an ability to recover from or adjust easily to misfortune or change; origin, Latin resilire, to jump back, recoil.
} 
this phenomenon the "Singapore Paradox"-Singapore, although highly exposed to external shocks, has managed to sustain relatively high rates of economic growth and GDP per capita. He explains the paradox in terms of the country's ability to build its economic resilience by structuring the economy so that it can offset the disadvantages associated with its economic vulnerability.

Briguglio $(2003,2004)$ posits that economic vulnerability reflects an economy's inherent features that are permanent or quasi-permanent. On the other hand, economic resilience is nurtured and associated with "manmade measures, which enable a country to withstand or bounce back from the negative effects of external shocks." As Briguglio, Cordina, Farrugia, and Vella (2009) note, the term has been used in the literature in at least three senses relating to the ability to (i) recover quickly from a shock"shock-counteraction", (ii) withstand the effect of a shock-"shockabsorption", and (iii) avoid the adverse impact of shocks—shock avoidance as the obverse of economic vulnerability. Briguglio (2004) classifies countries according to their high or low scores in terms of vulnerability and resilience, terming the four possible cases "best-case", "worst-case", "selfmade", and "prodigal son". Briguglio et al. (2009) go further and construct vulnerability and resilience indices for 87 countries, and provide ample evidence that countries differ considerably in these dimensions.

Our concept of vulnerability is closely related to the concepts of vulnerability and resilience discussed in the literature. However, we focus on economic vulnerability and resilience in a broader sense than previously used. We aim to assess how overall economic uncertainties are experienced by the populations in different economies along the recognized dimensions of human development. Their recent experience can be used as an indicator of the extent to which human development may be at risk. While earlier empirical research has focused on the determinants of economic vulnerability and resilience, we capture its overall effect in diminishing human wellbeing.

One pervasive theme in the development of human societies has been their endeavor to build social, political, and economic institutions that help reduce the uncertainties faced by individuals, communities, and economies. In the theory of choice under uncertainty, individual utility functions include a risk parameter to reflect risk aversion. In parallel, social welfare functions should also reflect risk aversion on the part of society. At the micro-level, it is argued that a major hurdle to poverty alleviation is the fact that at-risk populations continue to slip back into poverty due to 
economic shocks, thus providing one rationale for the need for social safety nets. We suggest that economic vulnerabilities need to be explicitly considered another dimension (negative) of human capabilities, and thus propose a U-HDI.

\section{A Proposed Measure for Adjusting for Economic Uncertainties}

The methodology for constructing a U-HDI uses the time variability of income changes as a proxy for economic vulnerability. Our approach is similar to that used to compute the IHDI following Atkinson (1970). Atkinson's approach, drawing on Dalton (1920), starts with the assertion that any statistical measure of inequality should be based directly on the form of the social welfare function $U(y)$ and the expected value of the utility function as the primary criterion for ranking income distribution:

$$
W=\int_{0}^{\bar{y}} U(y) f(y) d y
$$

Atkinson makes the usual assumptions about the form of the function $U(y)$ : it is increasing and concave. ${ }^{5} \mathrm{He}$ draws on the economic theories on decision-making under uncertainty and exploits the parallel to the second-order stochastic dominance criterion:

A distribution $f(y)$ will be preferred to another distribution $f^{*}(y)$ according to criterion (5) for all $U(y)\left(U^{\prime}>0, U^{\prime \prime}<0\right)$ if and only if

$$
\int_{0}^{2}\left[F(y)-F^{*}(y)\right] d y \leq 0 \text { for all } z, 0 \leq z \leq \bar{y}
$$

and $F(y) \neq F^{*}(y)$ for some $y$, where $F(x)=\int_{0}^{y} f(y) d x$.

Atkinson obtains a measure of inequality by introducing the concept of the equally distributed equivalent level of income $\left(y_{E D E}\right)$, or the level of income per head which, if equally distributed, would yield the same level of social welfare as the present distribution, that is:

$$
U\left(y_{E D E}\right) \int_{0}^{\bar{y}} f(y) d y=\int_{0}^{\bar{y}} U(y) f(y) d y
$$

His measure of inequality is 1 minus the ratio of the equally distributed equivalent level of income to the mean of the actual distribution, $I=1-y_{E D E} / \mu$. Atkinson notes that, "the concept of equally distributed equivalent income is closely related to that of a risk premium or

\footnotetext{
${ }^{5}$ The assumption that $U(y)$ is concave is equivalent to assuming that a person is risk-averse.
} 
certainty equivalent in the theory of decision-making under uncertainty. ${ }^{6}$ $Y_{E D E}$ is simply the analogue of the certainty equivalent and $I$ is equal to the proportional risk premium as defined by Pratt (1964)." This parallel, along with the requirement that inequality measures be invariant to proportional shifts in income-implying constant (relative) inequality-aversion-allows Atkinson to develop the following specific measure of inequality:

$$
I=1-\left[\sum_{i}\left(\frac{y_{i}}{\mu}\right)^{1-\epsilon} f\left(y_{i}\right)\right]^{1 /(1-\epsilon)}
$$

In the Atkinson measure of inequality, $I_{\varepsilon}=1-\mu_{1-\varepsilon} / \mu_{1}, \mu_{1-\varepsilon}$ uses a general class of means of order $\varepsilon$. For $\varepsilon>0$, the mean assigns greater weight to the lower part of the distribution; for $\varepsilon=0$, it is neutral; and for $\varepsilon<0$, it is more sensitive to the upper part. The higher the $\varepsilon$ the more emphasis is on the lower part of the distribution; therefore, the order $\varepsilon$ is interpreted as the degree of aversion toward inequality across persons. The IHDI draws on the Atkinson (1970) family of inequality measures and sets the aversion parameter $\varepsilon$ equal to 1 . In this case, the inequality measure is $A=1-\gamma / \mu$, where $\gamma$ is the geometric mean and $\mu$ the arithmetic mean of the distribution.

In constructing a U-HDI, our approach is parallel to that of Atkinson, drawing on the theory on decision making under uncertainty. While Atkinson's concept of an "equally distributed income equivalent" is based on the certainty equivalent measure, we make direct use of the latter and the risk-based measures associated with it. Whereas the inequality measure is concerned with the distribution of income/wealth across the economy at a point in time, we focus on the distribution of income/wealth in the time series frame. In doing so, we capture the risk dimension associated with a country's income insofar that the historical distribution may be used as an unbiased estimator of the risk associated with expected income or wealth in the future. We propose that an economy's risk dimension can be proxied by its expected variability. Following Atkinson, we then propose an index of economic uncertainties as the ratio of the geometric mean to the arithmetic mean of historical time-series of various HDIs.

\section{An Exploratory Exercise}

This section presents an exploratory exercise in constructing a UHDI. For this initial study, we focus on the income dimension of the HDI since it is easier to measure uncertainties in this dimension than in health

${ }^{6}$ Drawing on the literature on decision-making under uncertainty, Atkinson shows that the use of this concept is equivalent to condition (6). 
or education. We also limit our analysis to the HDI for the year 2011. The data is from the World Development Indicators database and spans the following economic variables for all available countries:

1. GDP growth (annual percent)

2. GDP per capita growth (annual percent)

3. GNI growth (annual percent)

4. GNI per capita growth (annual percent)

5. Household final consumption expenditure (annual percent growth)

6. Household final consumption expenditure per capita (annual percent growth)

7. Household final consumption expenditure, etc. (annual percent growth)

The arithmetic and geometric means are computed for the last ten years (2002-2011) for this series, and then used to construct an uncertainty measure (parallel to the Atkinson measure, $A$ ): $U=1-\gamma / \mu$. This is then used to adjust the income component of the HDI for the year 2011. As an illustration, U-HDIs based on household final consumption expenditure per capita are reported in Table A1 in Appendix 1. A summary of the rank changes and percentage losses in the HDI resulting from the adjustment for each economic indicator used is given in Table 1 below. 
Table 1: Summary statistics for adjustments to HDI

\begin{tabular}{|c|c|c|c|c|c|c|c|}
\hline \multicolumn{8}{|c|}{ A: Loss or gain in country rankings } \\
\hline Rank change & A1 & A2 & A3 & A4 & A5 & A6 & A7 \\
\hline Below -20 & 10 & 9 & 7 & 7 & 7 & 7 & 9 \\
\hline-20 to -15 & 2 & 4 & 4 & 4 & 3 & 3 & 3 \\
\hline-15 to -10 & 4 & 3 & 4 & 3 & 7 & 5 & 5 \\
\hline-10 to -5 & 8 & 11 & 6 & 6 & 6 & 8 & 8 \\
\hline-5 to 0 & 34 & 26 & 27 & 28 & 18 & 19 & 19 \\
\hline 0 to 5 & 96 & 101 & 81 & 81 & 46 & 45 & 44 \\
\hline 5 to 10 & 11 & 18 & 10 & 11 & 18 & 17 & 27 \\
\hline 10 to 15 & 4 & 5 & 2 & 1 & 11 & 11 & 14 \\
\hline 15 to 20 & 0 & 0 & 0 & 0 & 1 & 1 & 0 \\
\hline Above 20 & 0 & 0 & 0 & 0 & 0 & 0 & 0 \\
\hline Subtotal & 169 & 177 & 141 & 141 & 117 & 116 & 129 \\
\hline No change & 17 & 9 & 10 & 10 & 7 & 8 & 9 \\
\hline Total & 186 & 186 & 151 & 151 & 124 & 124 & 138 \\
\hline Minimum & -59 & -58 & -48 & -46 & -68 & -68 & -88 \\
\hline Maximum & 13 & 13 & 11 & 11 & 16 & 16 & 15 \\
\hline \multicolumn{8}{|c|}{ B: Percent loss in HDI due to uncertainty adjustment } \\
\hline Loss range & A1 & $\mathrm{A} 2$ & A3 & A4 & A5 & A6 & A7 \\
\hline 0 to $5 \%$ & 155 & 154 & 119 & 119 & 80 & 81 & 88 \\
\hline 5 to $10 \%$ & 13 & 14 & 12 & 12 & 17 & 16 & 18 \\
\hline 10 to $15 \%$ & 7 & 8 & 7 & 7 & 6 & 6 & 12 \\
\hline 15 to $20 \%$ & 4 & 3 & 5 & 6 & 9 & 10 & 5 \\
\hline Above $20 \%$ & 7 & 7 & 8 & 7 & 12 & 11 & 15 \\
\hline Total & 186 & 186 & 151 & 151 & 124 & 124 & 138 \\
\hline Min. (\%) & 0.1 & 0.1 & 0.1 & 0.0 & 0.1 & 0.1 & 0.1 \\
\hline Max. (\%) & 91.0 & 86.2 & 53.7 & 52.3 & 64.2 & 60.6 & 58.7 \\
\hline Average (\%) & 4.1 & 4.0 & 4.7 & 4.6 & 7.2 & 7.1 & 7.5 \\
\hline
\end{tabular}

Note: Adjustment based on economic variables: A1 = GDP growth (annual percent), A2 = GDP per capita growth (annual percent), A3 = GNI growth (annual percent), A4 = GNI per capita growth (annual percent), A5 = household final consumption expenditure (annual percent growth), A6 = household final consumption expenditure per capita growth (annual percent), A7 = household final consumption expenditure, etc. (annual percent growth).

Source: Authors' calculations. 
Panel A of Table 1 shows that the uncertainty adjustment leads to extensive changes in countries' ranks corresponding to each of the economic variables used in the adjustment. The number of countries varies from 124 to 186, according to the data available. Only between 7 to 17 out of a sample of 124 to 186 countries did not experience a change in their ranking; thus, the percentage of no change is 9.1 percent at the maximum $(17 / 186)$ and 4.8 percent at the minimum (9/186), corresponding to the economic variables GDP growth (annual percent) and GDP per capita growth (annual percent), respectively. There is also a wide range in the changes in ranking: seven to ten countries fall by more than 20 positions, while gains in ranks appear to be more moderate but still substantial.

Panel B of Table 1 reports the percent loss in the HDI (income component), computed as (1 - adjusted HDI/HDI) percent, for the sample countries for each of the variables (A1-A7) used for adjustment. The average loss resulting from uncertainty adjustment in the HDI ranges between 4 and 7.5 percent, but the experienced loss has a wide rangemaximum loss ranges from 52.3 to 91 percent, with 7 to 15 countries registering a loss greater than 20 percent in the HDI after incorporating the uncertainty dimension.

Figure 1 shows the percent loss in HDI (income component) after adjusting for uncertainty with respect to one economic variable, household final consumption expenditure per capita growth (annual percent). The percent loss is plotted against the HDI and some of the extreme cases are labeled. Pakistan's position is also labeled, which we discuss further in the next section. Appendix 2 includes similar figures with respect to the other adjusting variables. The pattern of the scatter shows that the percent loss does not appear to be related to the level of the HDI. This indicates that the impact of the adjustment for uncertainty captures a different dimension from income. 
Figure 1: Percent loss in HDI from adjusting for uncertainty

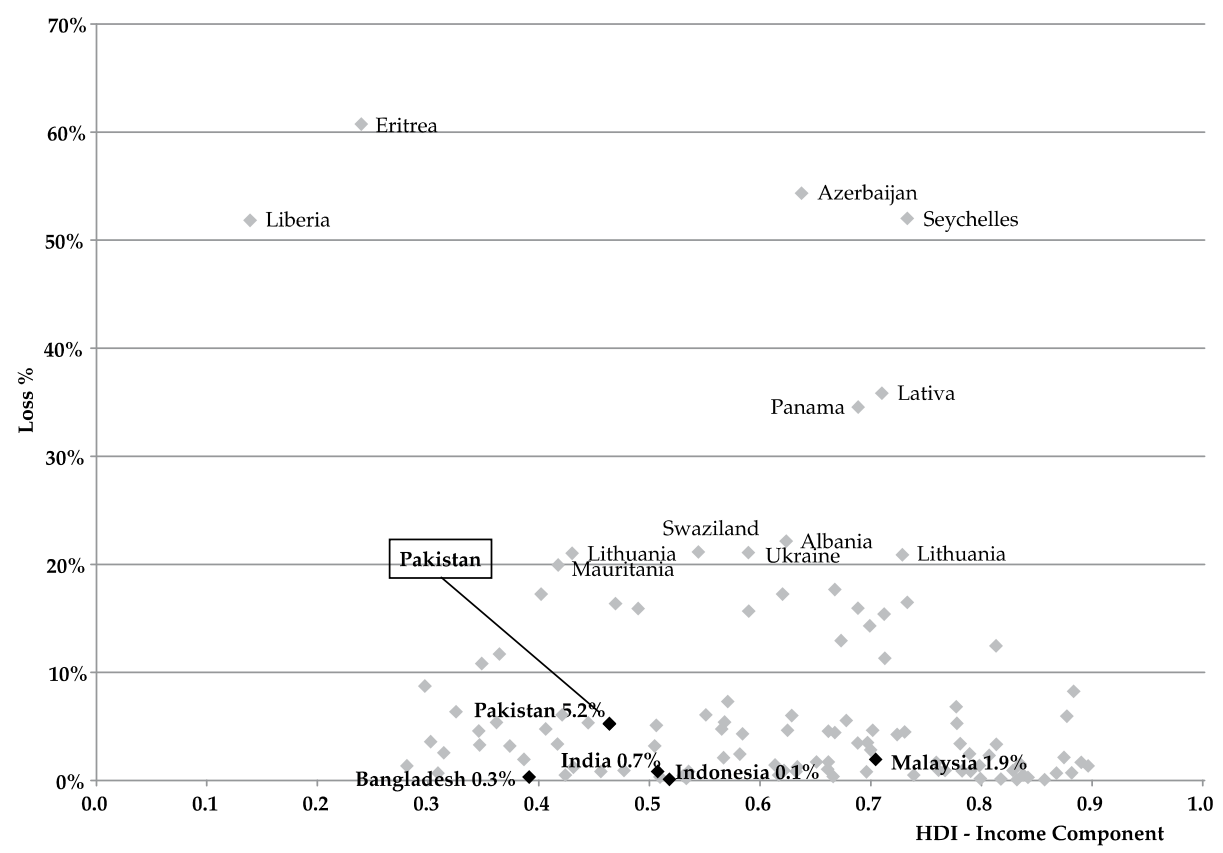

Table 2 reports the correlation coefficients for the HDI (income component) and percent loss and change in rank after adjustment based on seven different economic variables. The correlation coefficients are fairly low and insignificant, implying that the adjustment process does add new information to the HDI.

Table 2: Correlation of HDI with percent loss and rank changes

\begin{tabular}{lcc}
\hline Adjustment variable/correlation coefficient & Percent loss & $\begin{array}{c}\text { Rank } \\
\text { change }\end{array}$ \\
\hline GDP growth & -0.1407 & -0.0914 \\
GDP per capita growth & -0.1238 & -0.0909 \\
GNI growth & -0.1425 & -0.1031 \\
GNI per capita growth & -0.1356 & -0.1010 \\
Household consumption expenditure & -0.2529 & -0.1737 \\
Household final consumption expenditure per & -0.2395 & -0.1736 \\
capita & & \\
Household final consumption expenditure, etc. & -0.2198 & -0.1800 \\
\hline
\end{tabular}

Source: Authors' calculations. 
Additionally, the countries with the greatest loss from adjustment (see Table 3) seem to include those that have experienced conflict, extraordinary political and social unrest, and economic hardship following the global financial crisis, greatly affecting people's wellbeing. This association provides intuitive support to the case for considering economic uncertainties a relevant dimension of evaluating human development.

Table 3: Countries with $>20$ percent loss from adjustment

\begin{tabular}{lcccc}
\hline Country & $\begin{array}{c}\text { HDI } \\
\text { (income) }\end{array}$ & $\begin{array}{c}\text { Adj. HDI } \\
\text { (income) }\end{array}$ & $\begin{array}{c}\text { Rank } \\
\text { change }\end{array}$ & $\begin{array}{c}\text { Loss from } \\
\text { uncertainty (\%) }\end{array}$ \\
\hline Eritrea & 0.240 & 0.0946 & 0 & 60.6 \\
Azerbaijan & 0.639 & 0.2924 & -53 & 54.2 \\
Seychelles & 0.733 & 0.3520 & -68 & 52.0 \\
Liberia & 0.140 & 0.0673 & 0 & 51.8 \\
Latvia & 0.711 & 0.4562 & -46 & 35.8 \\
Panama & 0.690 & 0.4515 & -39 & 34.5 \\
Albania & 0.624 & 0.4865 & -16 & 22.0 \\
Ukraine & 0.591 & 0.4658 & -12 & 21.1 \\
Swaziland & 0.545 & 0.4299 & -9 & 21.1 \\
Kyrgyz Republic & 0.432 & 0.3413 & -8 & 20.9 \\
Lithuania & 0.729 & 0.5767 & -28 & 20.9 \\
Mauritania & 0.419 & 0.3349 & -6 & 20.0 \\
\hline
\end{tabular}

Source: Authors' calculations.

The HDI and the U-HDI are plotted for the sample countries in Figure 2. Again, the plot is based on adjustment with respect to the economic variable household final consumption expenditure per capita growth. The figure shows that the adjustment procedure affects most of the sample countries, with some registering a substantial decline in the HDI. Again, an obvious observation would be that countries with greater reductions in the HDI seem to be those that have experienced a high degree of variability in their political, social, or economic environment. There is also a degree of positive association between the HDI and the adjusted HDI, which should be expected since one is obtained from the other. Some positive dependence arises arguably because developed and higher-income countries are characterized by a more stable environment due to many factors such as economic size, institutional maturity, and a better capacity for macroeconomic management (or being less vulnerable as well as more resilient). 


\section{Figure 2: Plot of HDI and adjusted HDI}

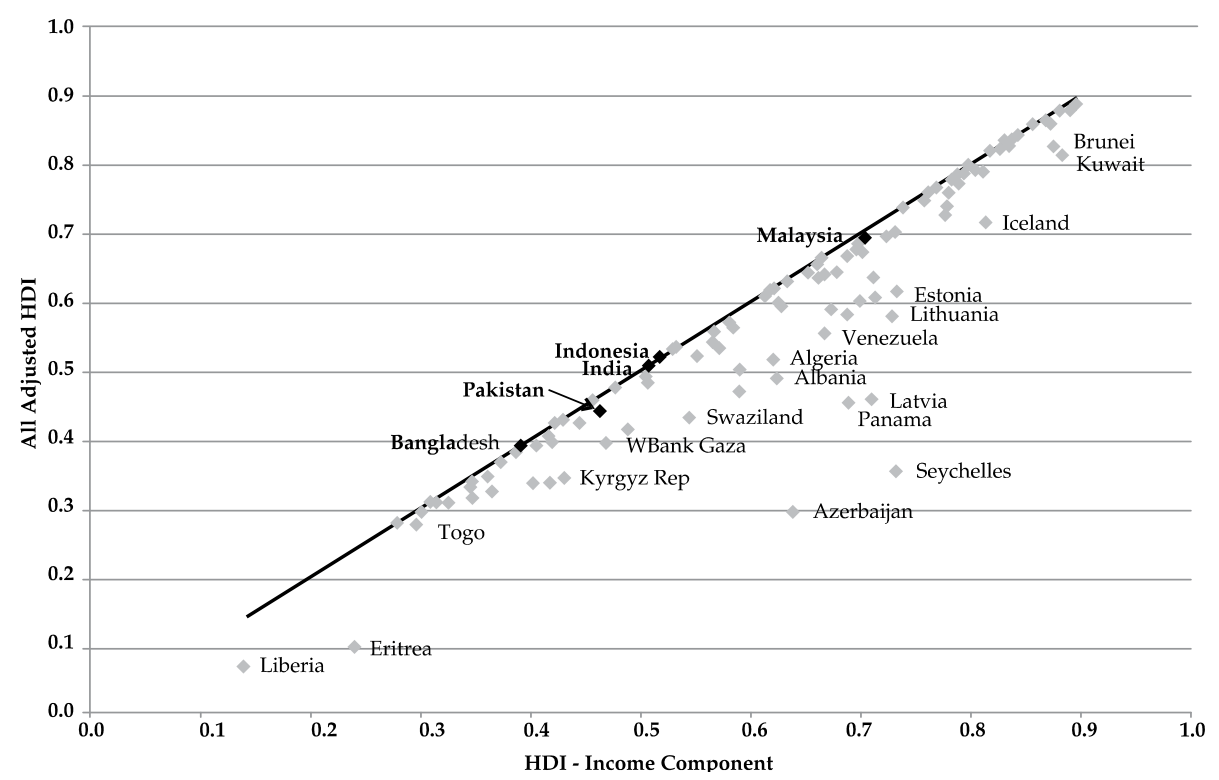

\section{The Case of Pakistan}

The HDI is an indicator of much interest for Pakistan, which lags behind in human and social development in the region. The HDR groups Pakistan among the countries with "low human development;" according to the 2011 HDR, out of a total of 179 countries, Pakistan is ranked 145, Bangladesh 146, Nepal 157, and Afghanistan 172. In the South Asian region, India and Sri Lanka are grouped as countries with "medium human development" with ranking of 134 and 92, respectively. ${ }^{7}$

When we adjust the income component of the HDI for uncertainty, we find that Pakistan compares less favorably relative to the countries in the region. Table 4 presents the results of this adjustment for a selected group of countries that are typically held out as peers to Pakistan. The percent loss in the HDI-income component for Pakistan is 5.2 percent, which is quite high relative to other countries; for example, it is 0.7 percent for India and 0.3 percent for Bangladesh. The next highest-loss country is Egypt with a loss of 2.1 percent-less than half that of Pakistan.

\footnotetext{
${ }^{7}$ According to the most recent HDR (UNDP, 2013) the HDI 2012 country rankings are not very different from the previous year; these are: Pakistan at 146, Bangladesh at 146, Nepal at 157, Afghanistan at 175, India at 136, and Sri Lanka at 92.
} 
Table 4: Selected countries in comparison with Pakistan

\begin{tabular}{lccccccc}
\hline & \multicolumn{2}{c}{$\begin{array}{c}\text { HDI (income } \\
\text { component) }\end{array}$} & \multicolumn{2}{c}{ HDI (income) } & & \multicolumn{2}{c}{$\begin{array}{c}\text { Percent } \\
\text { loss in }\end{array}$} \\
\cline { 2 - 5 } Country & $\begin{array}{c}\text { HDI before } \\
\text { adjustment }\end{array}$ & $\begin{array}{c}\text { HDI after } \\
\text { adjustment }\end{array}$ & $\begin{array}{c}\text { Before } \\
\text { adjustment }\end{array}$ & $\begin{array}{c}\text { After } \\
\text { adjustment }\end{array}$ & $\begin{array}{c}\text { Rank } \\
\text { change }\end{array}$ & $\begin{array}{c}\text { HDI from } \\
\text { adjustment }\end{array}$ \\
\cline { 2 - 5 } Thailand & 0.622 & 0.6163 & 72 & 59 & 13 & 0.9 \\
Egypt & 0.568 & 0.5560 & 83 & 72 & 11 & 2.1 \\
Indonesia & 0.518 & 0.5172 & 90 & 81 & 9 & 0.1 \\
Philippines & 0.508 & 0.5073 & 91 & 83 & 8 & 0.2 \\
India & 0.508 & 0.5041 & 92 & 84 & 8 & 0.7 \\
Vietnam & 0.478 & 0.4734 & 96 & 89 & 7 & 0.9 \\
Pakistan & 0.464 & 0.4398 & 98 & 94 & 4 & 5.2 \\
Bangladesh & 0.391 & 0.3896 & 109 & 103 & 6 & 0.3 \\
Kenya & 0.387 & 0.3798 & 110 & 105 & 5 & 1.9 \\
\hline
\end{tabular}

Source: Authors' calculations.

In order to better understand how the adjusted HDI might reflect the uncertainties underlying an economy, we trace the percent loss from the uncertainty adjustment over time for Pakistan over the period 19722011. We compute the percent loss based on a rolling window of five years, which equals the moving ratio of the geometric mean to the arithmetic mean, using the GNI per capita growth (annual percent) series. The resulting loss indicator series is depicted in Figure 3, each point plotted against the ending year of the moving window, thus reflecting the experience of the previous five years. Major economic and political events are marked on the graph, which also shows the various political regimes that have been in power over this period to bring into relief the country's political and economic climate over time. 
Figure 3: Percent loss in HDI from adjusting for uncertainty over time

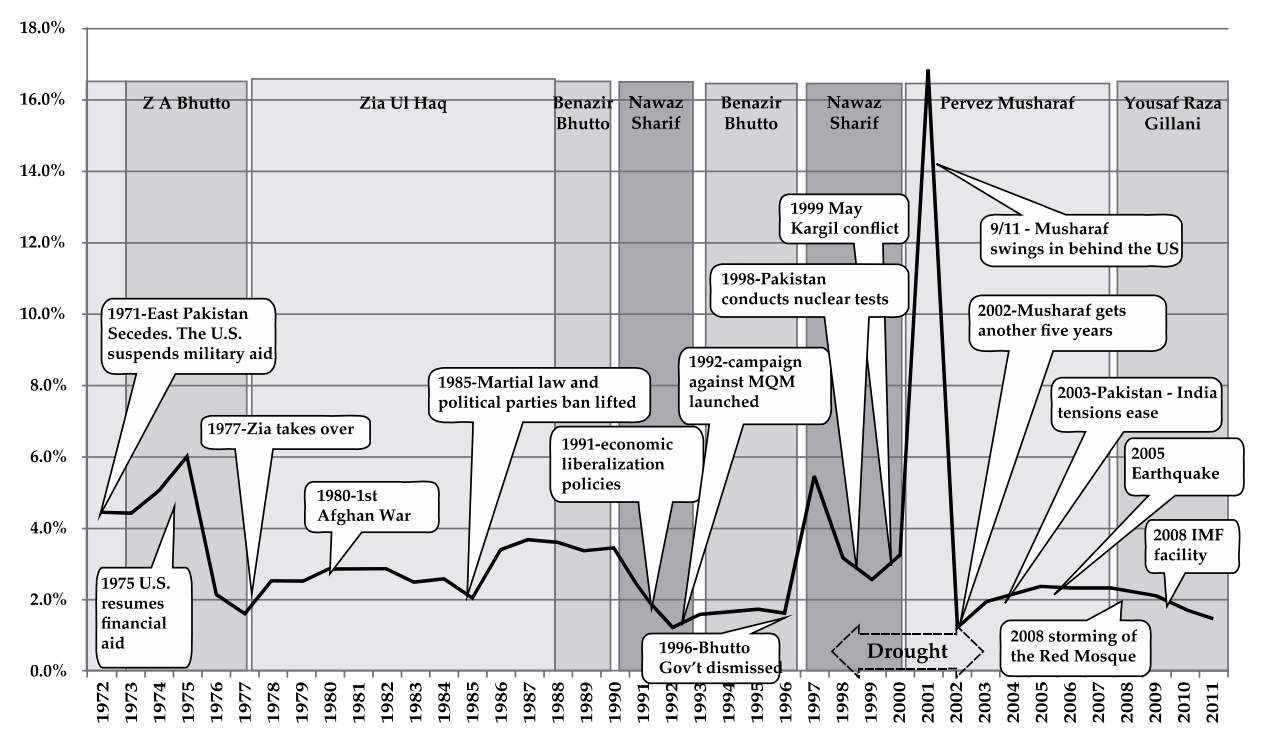

As the figure indicates, the computed percent loss due to uncertainty seems to reflect the uncertainties related to the political and economic environment in various periods. Thus, the increasing values of the loss indicator over 1972-75 captures the political and economic disruption associated with the secession of Bangladesh. After 1975, it declines sharply as the new constitution is enacted. The second half of the Zulfikar Ali Bhutto period, however, sees the indictor rise, reflecting greater uncertainties associated with political unrest, disruptions to economic aid, and the eventual takeover of the government by General Zia-ul-Haq. The indicator remains elevated during Zia's rule and rises further toward the end of the 1980s as the anti-Soviet war in Afghanistan escalates. It declines after the Soviets withdraw in 1989, but is ramped up again as Afghanistan is engulfed in another round of power struggles.

There is a sharp increase in the loss indicator (marked against the year 2001), which captures the political disruptions and economic uncertainties of the preceding years. These include Pakistan conducting nuclear tests (1998), the imposition of economic sanctions, the May 1999 Kargil conflict, the ouster of Nawaz Sharif in the 1999 coup, and finally the events of $9 / 11$. The indicator subsides as the Musharraf government settles down and aligns with the US war on terror, assuring a renewed stream of foreign aid and a period of stable economic growth. Finally, in the more recent period, the loss indicator seems to follow a declining trend. 


\section{Summary and Conclusions}

The 2010 HDR acknowledges that the ideal measure of human development covers more than the three core dimensions currently included. This study has explored such a new dimension of human development, i.e., the extent to which economies face systemic uncertainties, rendering development vulnerable and diminishing human capabilities. We have presented the case that economic uncertainties need to be explicitly considered another dimension of human capabilities, since they directly diminish social welfare and constrain human capabilities.

Our methodology for constructing a U-HDI parallels the approach used by the HDR to construct an IHDI, using the time variability of income changes as a proxy for economic vulnerability instead of intra-country income inequalities.

We have constructed a U-HDI associated with the income component of the HDI for the year 2011 on the suggested lines for a crosssection of countries. Our preliminary analysis indicates that such an index seems to contain additional information beyond the income index. The percent loss in the income component of the HDI appears to reflect the variability in national economic indicators arising from the political and economic tribulations experienced by each country. We have also presented a time-series perspective of the percent loss from the uncertainty adjustment for Pakistan. In this case, the loss indicator closely traces the political and economic upheavals experienced by the country over a 40year period. Both the cross-sectional and time-series behavior of the adjustment loss indicator thus appears to validate its conceptual foundation.

Our empirical analysis of the proposed measure should, however, be tempered by a number of limitations. First, the use of annual data obviously limits the measure's usefulness as a proxy for underlying economic vulnerabilities. Other higher-frequency time series, if available, might measure the underlying concept more precisely. Second, history is seldom a perfect predictor of the future, and the vulnerability proxy based on historical data obviously ignores any structural shifts and developments in the institutional, regulatory, or governance framework that might otherwise render it invalid as a predictor. Third, the use of aggregate national-level economic indicators hides the uncertainties that are faced by individuals, communities, and regional or sub-national groups. 


\section{References}

Alkire, S. (2002). Dimensions of human development. World Development, 30(2), 181-205.

Alkire, S., \& Foster, J. (2011). Understandings and misunderstandings of multidimensional poverty measurement (Working Paper No. 43). Oxford, UK: University of Oxford, Oxford Poverty and Human Development Initiative.

Atkins, J., Mazzi, S., \& Easter, C. (2000). A commonwealth vulnerability index for developing countries: The position of small states. London, UK: Commonwealth Secretariat.

Atkinson, A. B. (1970). On the measurement of inequality. Journal of Economic Theory, 2, 244-263.

Briguglio, L. (1995). Small island states and their economic vulnerabilities. World Development, 23(9), 1615-1632.

Briguglio, L. (2003). The vulnerability index and small island developing states: A review of conceptual and methodological issues. Paper prepared for the AIMS Regional Preparatory Meeting on the Ten-Year Review of the Barbados Programme of Action, Praia, Cape Verde.

Briguglio, L. (2004). Economic vulnerability and resilience: Concepts and measurements. In L. Briguglio \& E. J. Kisanga (Eds.), Economic vulnerability and resilience of small states. Malta: Islands and Small States Institute.

Briguglio, L., Cordina, G., Farrugia, N., \& Vella, S. (2009). Economic vulnerability and resilience: Concepts and measurements. Oxford Development Studies, 37(3), 229-247.

Briguglio, L., \& Galea, W. (2003). Updating and augmenting the economic vulnerability index (Occasional Papers on Islands and Small States, No. 2003-4). Malta: Islands and Small States Institute.

Cordina, G. (2004a). Economic vulnerability, resilience and capital formation. In L. Briguglio \& E. J. Kisanga (Eds.), Economic vulnerability and resilience of small states (pp. 104-112). Malta: Islands and Small States Institute. 
Cordina, G. (2004b). Economic vulnerability and economic growth: Some results from a neoclassical growth modeling approach. Journal of Economic Development, 29(2), 21-39.

Crowards, T. (2000). An index of inherent economic vulnerability for developing countries (Staff Working Paper No. 6/00). Barbados: Caribbean Development Bank.

Dalton, H. (1920). The measurement of the inequality of incomes. The Economic Journal, 30, 348-361.

Dasgupta, P., \& Weale, M. (1992). On measuring the quality of life. World Development, 20(1), 119-131.

Haq, M. (1995). Reflections on human development. New York, NY: Oxford University Press.

Kovacevic, M. (2011). Review of HDI critiques and potential improvements (Human Development Research Paper No. 2010/33). New York, NY: United Nations Development Programme.

Klugman, J., Rodríguez, F., \& Choi, H.-J. (2011). The HDI 2010: New controversies, old critiques (Human Development Research Paper No. 2011/01). New York, NY: United Nations Development Programme.

Lustig, N. (2011). Multidimensional indices of achievements and poverty: What do we gain and what do we lose? (Working Paper No. 262). Washington, DC: Center for Global Development.

Nussbaum, M. (2000). Women and human development: The capabilities approach. Cambridge, UK: Cambridge University Press.

Pratt, J. W. (1964). Risk aversion in the small and in the large. Econometrica, 32, 122-136.

Ravallion, M. (2010). Troubling tradeoffs in the human development index (Policy Research Working Paper No. 5484). Washington, DC: World Bank.

Sagar, A. D., \& Najam, A. (1998). The human development index: A critical review. Ecological Economics, 25(3), 249-264. 
Sen, A. K. (1985). Commodities and capabilities. Amsterdam: Elsevier.

Sen, A. K. (1990). Development as capability expansion. In K. Griffin \& J. Knight (Eds.), Human development and the international development strategy for the 1990s (pp. 41-58). London, UK: Macmillan.

Sen, A. K. (1999). Development as freedom. Oxford, UK: Oxford University Press.

Sen, A. K. (2002). Rationality and freedom. Cambridge, MA: Harvard University Press.

Sen, A. K. (2008). The economics of happiness and capability. In L. Bruni, F. Comim, \& M. Pugno (Eds.), Capabilities and happiness (pp. 1627). Oxford, UK: Oxford University Press.

United Nations Development Programme. (1990). Human development report 1990: Concept and measurement of human development. New York, NY: Oxford University Press.

United Nations Development Programme. (2010). Human development report 2010 - The real wealth of nations: Pathways to human development. New York, NY: Palgrave Macmillan.

United Nations Development Programme. (2011). Human development report 2011 - Sustainability and equity: A better future for all. New York, NY: Palgrave Macmillan.

United Nations Development Programme. (2013). Human development report 2013 - The rise of the south: Human progress in a diverse world. New York, NY: Palgrave Macmillan. 


\section{Appendix 1}

Table A1: Uncertainty adjustment to HDI using household final consumption expenditure per capita growth

\begin{tabular}{|c|c|c|c|c|c|c|c|}
\hline Country & $\begin{array}{l}\text { HDI } \\
\text { rank }\end{array}$ & $\begin{array}{c}\text { HDI } \\
\text { (income) }\end{array}$ & $\begin{array}{c}\text { Uncertainty- } \\
\text { adjusted } \\
\text { HDI }\end{array}$ & $\begin{array}{c}\text { Rank } \\
\text { (income } \\
\text { HDI) }\end{array}$ & $\begin{array}{l}\text { Rank } \\
\text { (adj. } \\
\text { HDI) }\end{array}$ & $\begin{array}{c}\text { Rank } \\
\text { change }\end{array}$ & $\begin{array}{c}\text { Percent } \\
\text { loss from } \\
\text { adjustment }\end{array}$ \\
\hline Singapore & 26 & 0.897 & 0.8852 & 1 & 1 & 0 & 1.3 \\
\hline Luxembourg & 25 & 0.892 & 0.8770 & 2 & 2 & 0 & 1.6 \\
\hline Kuwait & 63 & 0.884 & 0.8114 & 3 & 19 & -16 & 8.2 \\
\hline Norway & 1 & 0.883 & 0.8767 & 4 & 3 & 1 & 0.7 \\
\hline Brunei Darussalam & 33 & 0.877 & 0.8256 & 5 & 14 & -9 & 5.9 \\
\hline Hong Kong & 13 & 0.874 & 0.8557 & 6 & 6 & 0 & 2.1 \\
\hline US & 4 & 0.869 & 0.8629 & 7 & 4 & 3 & 0.6 \\
\hline Switzerland & 11 & 0.858 & 0.8572 & 8 & 5 & 3 & 0.1 \\
\hline Netherlands & 3 & 0.845 & 0.8416 & 9 & 7 & 2 & 0.4 \\
\hline Sweden & 10 & 0.842 & 0.8390 & 10 & 9 & 1 & 0.4 \\
\hline Austria & 19 & 0.842 & 0.8410 & 11 & 8 & 3 & 0.1 \\
\hline Canada & 6 & 0.840 & 0.8371 & 12 & 11 & 1 & 0.3 \\
\hline Germany & 9 & 0.838 & 0.8376 & 13 & 10 & 3 & 0.1 \\
\hline Australia & 2 & 0.837 & 0.8321 & 14 & 12 & 2 & 0.5 \\
\hline Denmark & 16 & 0.836 & 0.8241 & 15 & 15 & 0 & 1.5 \\
\hline Belgium & 18 & 0.832 & 0.8315 & 16 & 13 & 3 & 0.1 \\
\hline UK & 28 & 0.832 & 0.8211 & 17 & 16 & 1 & 1.3 \\
\hline Finland & 22 & 0.828 & 0.8208 & 18 & 17 & 1 & 0.9 \\
\hline France & 20 & 0.819 & 0.8180 & 19 & 18 & 1 & 0.1 \\
\hline Iceland & 14 & 0.814 & 0.7124 & 20 & 37 & -17 & 12.5 \\
\hline Ireland & 7 & 0.814 & 0.7872 & 21 & 24 & -3 & 3.3 \\
\hline Rep. of Korea & 15 & 0.808 & 0.7894 & 22 & 21 & 1 & 2.3 \\
\hline Spain & 23 & 0.799 & 0.7889 & 23 & 22 & 1 & 1.3 \\
\hline Italy & 24 & 0.799 & 0.7976 & 24 & 20 & 4 & 0.2 \\
\hline Israel & 17 & 0.796 & 0.7881 & 25 & 23 & 2 & 0.9 \\
\hline Slovenia & 21 & 0.790 & 0.7831 & 26 & 25 & 1 & 0.9 \\
\hline Cyprus & 31 & 0.790 & 0.7711 & 27 & 27 & 0 & 2.4 \\
\hline Greece & 29 & 0.783 & 0.7580 & 28 & 30 & -2 & 3.3 \\
\hline New Zealand & 5 & 0.783 & 0.7768 & 29 & 26 & 3 & 0.8 \\
\hline Saudi Arabia & 56 & 0.781 & 0.7551 & 30 & 32 & -2 & 3.3 \\
\hline The Bahamas & 53 & 0.779 & 0.7382 & 31 & 34 & -3 & 5.2 \\
\hline Oman & 89 & 0.778 & 0.7247 & 32 & 36 & -4 & 6.8 \\
\hline Malta & 36 & 0.769 & 0.7623 & 33 & 28 & 5 & 0.9 \\
\hline Czech Rep. & 27 & 0.769 & 0.7619 & 34 & 29 & 5 & 0.9 \\
\hline Portugal & 41 & 0.763 & 0.7561 & 35 & 31 & 4 & 0.9 \\
\hline Slovak Rep. & 35 & 0.759 & 0.7459 & 36 & 33 & 3 & 1.7 \\
\hline Poland & 39 & 0.739 & 0.7361 & 37 & 35 & 2 & 0.4 \\
\hline Estonia & 34 & 0.734 & 0.6132 & 38 & 61 & -23 & 16.4 \\
\hline
\end{tabular}




\begin{tabular}{|c|c|c|c|c|c|c|c|}
\hline Country & $\begin{array}{l}\text { HDI } \\
\text { rank }\end{array}$ & $\begin{array}{c}\text { HDI } \\
\text { (income) }\end{array}$ & $\begin{array}{c}\text { Uncertainty- } \\
\text { adjusted } \\
\text { HDI }\end{array}$ & $\begin{array}{c}\text { Rank } \\
\text { (income } \\
\text { HDI) }\end{array}$ & $\begin{array}{c}\text { Rank } \\
\text { (adj. } \\
\text { HDI) }\end{array}$ & $\begin{array}{c}\text { Rank } \\
\text { change }\end{array}$ & $\begin{array}{c}\text { Percent } \\
\text { loss from } \\
\text { adjustment }\end{array}$ \\
\hline Seychelles & 52 & 0.733 & 0.3520 & 39 & 107 & -68 & 52.0 \\
\hline Hungary & 38 & 0.732 & 0.6997 & 40 & 38 & 2 & 4.4 \\
\hline Lithuania & 40 & 0.729 & 0.5767 & 41 & 69 & -28 & 20.9 \\
\hline Croatia & 46 & 0.724 & 0.6942 & 42 & 39 & 3 & 4.2 \\
\hline Russian Fed. & 66 & 0.713 & 0.6035 & 43 & 63 & -20 & 15.4 \\
\hline Argentina & 45 & 0.713 & 0.6331 & 44 & 55 & -11 & 11.2 \\
\hline Latvia & 43 & 0.711 & 0.4562 & 45 & 91 & -46 & 35.8 \\
\hline Malaysia & 61 & 0.704 & 0.6912 & 46 & 40 & 6 & 1.9 \\
\hline Belarus & 65 & 0.702 & 0.6694 & 47 & 46 & 1 & 4.6 \\
\hline Chile & 44 & 0.701 & 0.6816 & 48 & 42 & 6 & 2.7 \\
\hline Mexico & 57 & 0.700 & 0.6801 & 49 & 43 & 6 & 2.8 \\
\hline Uruguay & 48 & 0.700 & 0.6000 & 50 & 64 & -14 & 14.3 \\
\hline Lebanon & 71 & 0.698 & 0.6743 & 51 & 44 & 7 & 3.4 \\
\hline Botswana & 118 & 0.698 & 0.6736 & 52 & 45 & 7 & 3.5 \\
\hline Mauritius & 77 & 0.696 & 0.6912 & 53 & 41 & 12 & 0.7 \\
\hline Panama & 58 & 0.690 & 0.4515 & 54 & 93 & -39 & 34.5 \\
\hline Gabon & 106 & 0.689 & 0.5794 & 55 & 68 & -13 & 15.9 \\
\hline Turkey & 92 & 0.689 & 0.6652 & 56 & 47 & 9 & 3.4 \\
\hline Bulgaria & 55 & 0.678 & 0.6409 & 57 & 52 & 5 & 5.5 \\
\hline Romania & 50 & 0.674 & 0.5871 & 58 & 67 & -9 & 12.9 \\
\hline Venezuela & 73 & 0.669 & 0.5513 & 59 & 73 & -14 & 17.5 \\
\hline Kazakhstan & 68 & 0.668 & 0.6381 & 60 & 53 & 7 & 4.4 \\
\hline Costa Rica & 69 & 0.667 & 0.6637 & 61 & 48 & 13 & 0.4 \\
\hline Serbia & 59 & 0.663 & 0.6334 & 62 & 54 & 8 & 4.5 \\
\hline Iran & 88 & 0.662 & 0.6549 & 63 & 49 & 14 & 1.1 \\
\hline Brazil & 84 & 0.662 & 0.6511 & 64 & 50 & 14 & 1.6 \\
\hline South Africa & 123 & 0.652 & 0.6413 & 65 & 51 & 14 & 1.6 \\
\hline Azerbaijan & 91 & 0.639 & 0.2924 & 66 & 119 & -53 & 54.2 \\
\hline Peru & 80 & 0.634 & 0.6271 & 67 & 57 & 10 & 1.1 \\
\hline Colombia & 87 & 0.633 & 0.6286 & 68 & 56 & 12 & 0.7 \\
\hline Dominican Rep. & 98 & 0.629 & 0.5913 & 69 & 66 & 3 & 6.0 \\
\hline Dominica & 81 & 0.626 & 0.5967 & 70 & 65 & 5 & 4.6 \\
\hline Albania & 70 & 0.624 & 0.4865 & 71 & 87 & -16 & 22.0 \\
\hline Thailand & 103 & 0.622 & 0.6163 & 72 & 59 & 13 & 0.9 \\
\hline Algeria & 96 & 0.621 & 0.5146 & 73 & 82 & -9 & 17.2 \\
\hline Ecuador & 83 & 0.620 & 0.6172 & 74 & 58 & 16 & 0.5 \\
\hline China & 101 & 0.618 & 0.6153 & 75 & 60 & 15 & 0.4 \\
\hline Tunisia & 94 & 0.614 & 0.6060 & 76 & 62 & 14 & 1.3 \\
\hline Namibia & 120 & 0.591 & 0.4988 & 77 & 85 & -8 & 15.6 \\
\hline Ukraine & 76 & 0.591 & 0.4658 & 78 & 90 & -12 & 21.1 \\
\hline El Salvador & 105 & 0.585 & 0.5599 & 79 & 71 & 8 & 4.2 \\
\hline Belize & 93 & 0.582 & 0.5681 & 80 & 70 & 10 & 2.4 \\
\hline Cuba & 51 & 0.572 & 0.5301 & 81 & 78 & 3 & 7.3 \\
\hline
\end{tabular}




\begin{tabular}{|c|c|c|c|c|c|c|c|}
\hline Country & $\begin{array}{l}\text { HDI } \\
\text { rank }\end{array}$ & $\begin{array}{c}\text { HDI } \\
\text { (income) }\end{array}$ & $\begin{array}{c}\text { Uncertainty- } \\
\text { adjusted } \\
\text { HDI }\end{array}$ & $\begin{array}{c}\text { Rank } \\
\text { (income } \\
\text { HDI) }\end{array}$ & $\begin{array}{c}\text { Rank } \\
\text { (adj. } \\
\text { HDI) }\end{array}$ & $\begin{array}{c}\text { Rank } \\
\text { change }\end{array}$ & $\begin{array}{c}\text { Percent } \\
\text { loss from } \\
\text { adjustment }\end{array}$ \\
\hline Jordan & 95 & 0.569 & 0.5378 & 82 & 75 & 7 & 5.4 \\
\hline Egypt & 113 & 0.568 & 0.5560 & 83 & 72 & 11 & 2.1 \\
\hline Armenia & 86 & 0.566 & 0.5390 & 84 & 74 & 10 & 4.7 \\
\hline Paraguay & 107 & 0.552 & 0.5191 & 85 & 80 & 5 & 6.0 \\
\hline Swaziland & 140 & 0.545 & 0.4299 & 86 & 95 & -9 & 21.1 \\
\hline Morocco & 130 & 0.535 & 0.5309 & 87 & 77 & 10 & 0.8 \\
\hline Guatemala & 131 & 0.534 & 0.5334 & 88 & 76 & 12 & 0.2 \\
\hline Bolivia & 108 & 0.530 & 0.5285 & 89 & 79 & 10 & 0.3 \\
\hline Indonesia & 124 & 0.518 & 0.5172 & 90 & 81 & 9 & 0.1 \\
\hline Philippines & 112 & 0.508 & 0.5073 & 91 & 83 & 8 & 0.2 \\
\hline India & 134 & 0.508 & 0.5041 & 92 & 84 & 8 & 0.7 \\
\hline Honduras & 121 & 0.507 & 0.4815 & 93 & 88 & 5 & 5.0 \\
\hline Cape Verde & 133 & 0.505 & 0.4894 & 94 & 86 & 8 & 3.1 \\
\hline Moldova & 111 & 0.490 & 0.4122 & 95 & 99 & -4 & 15.9 \\
\hline Vietnam & 128 & 0.478 & 0.4734 & 96 & 89 & 7 & 0.9 \\
\hline West Bank and Gaza & 114 & 0.470 & 0.3933 & 97 & 102 & -5 & 16.3 \\
\hline Pakistan & 145 & 0.464 & 0.4398 & 98 & 94 & 4 & 5.2 \\
\hline Nicaragua & 129 & 0.457 & 0.4528 & 99 & 92 & 7 & 0.9 \\
\hline Lao PDR & 138 & 0.445 & 0.4219 & 100 & 98 & 2 & 5.3 \\
\hline Kyrgyz Rep. & 126 & 0.432 & 0.3413 & 101 & 109 & -8 & 20.9 \\
\hline Cameroon & 150 & 0.431 & 0.4258 & 102 & 96 & 6 & 1.3 \\
\hline Tajikistan & 127 & 0.425 & 0.4224 & 103 & 97 & 6 & 0.5 \\
\hline Sudan & 169 & 0.421 & 0.3957 & 104 & 101 & 3 & 6.1 \\
\hline Mauritania & 159 & 0.419 & 0.3349 & 105 & 111 & -6 & 20.0 \\
\hline Cambodia & 139 & 0.418 & 0.4037 & 106 & 100 & 6 & 3.4 \\
\hline Senegal & 155 & 0.406 & 0.3872 & 107 & 104 & 3 & 4.7 \\
\hline Lesotho & 160 & 0.403 & 0.3338 & 108 & 112 & -4 & 17.1 \\
\hline Bangladesh & 146 & 0.391 & 0.3896 & 109 & 103 & 6 & 0.3 \\
\hline Kenya & 143 & 0.387 & 0.3798 & 110 & 105 & 5 & 1.9 \\
\hline Benin & 167 & 0.374 & 0.3626 & 111 & 106 & 5 & 3.1 \\
\hline The Gambia & 168 & 0.365 & 0.3229 & 112 & 114 & -2 & 11.6 \\
\hline Zambia & 164 & 0.362 & 0.3427 & 113 & 108 & 5 & 5.4 \\
\hline Burkina Faso & 181 & 0.349 & 0.3115 & 114 & 115 & -1 & 10.7 \\
\hline Uganda & 161 & 0.347 & 0.3353 & 115 & 110 & 5 & 3.2 \\
\hline Mali & 175 & 0.346 & 0.3306 & 116 & 113 & 3 & 4.6 \\
\hline Ethiopia & 174 & 0.326 & 0.3052 & 117 & 118 & -1 & 6.2 \\
\hline Mozambique & 184 & 0.314 & 0.3066 & 118 & 116 & 2 & 2.5 \\
\hline Guinea & 178 & 0.309 & 0.3064 & 119 & 117 & 2 & 0.7 \\
\hline Madagascar & 151 & 0.302 & 0.2913 & 120 & 120 & 0 & 3.6 \\
\hline Togo & 162 & 0.297 & 0.2716 & 121 & 122 & -1 & 8.7 \\
\hline Central African Rep. & 179 & 0.280 & 0.2765 & 122 & 121 & 1 & 1.3 \\
\hline Eritrea & 177 & 0.240 & 0.0946 & 123 & 123 & 0 & 60.6 \\
\hline Liberia & 182 & 0.140 & 0.0673 & 124 & 124 & 0 & 51.8 \\
\hline
\end{tabular}




\section{Appendix 2}

Figure A1: GDP growth

(annual percent)
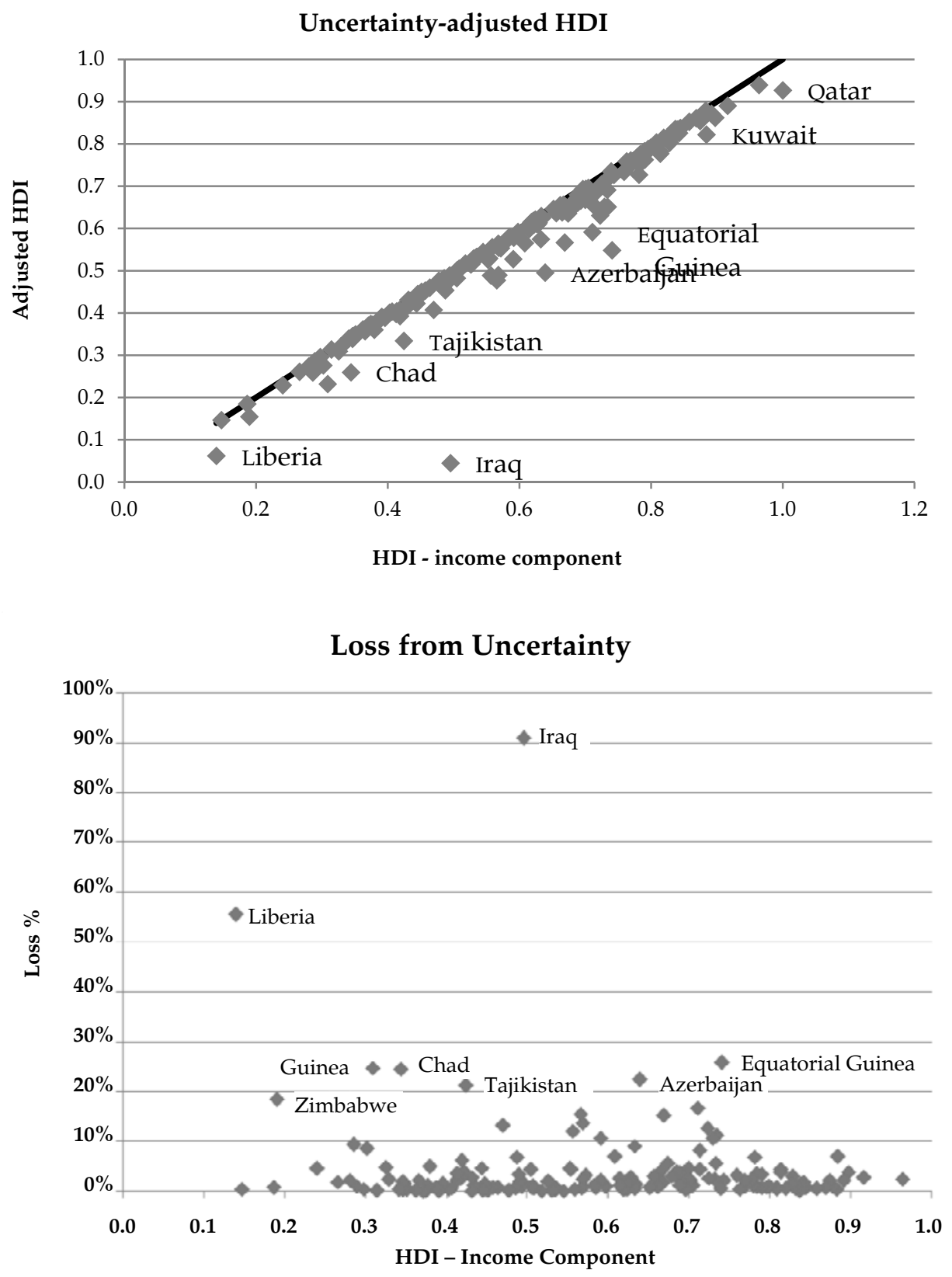
Figure A2: GDP per capita growth (annual percent)

Loss from uncertainty

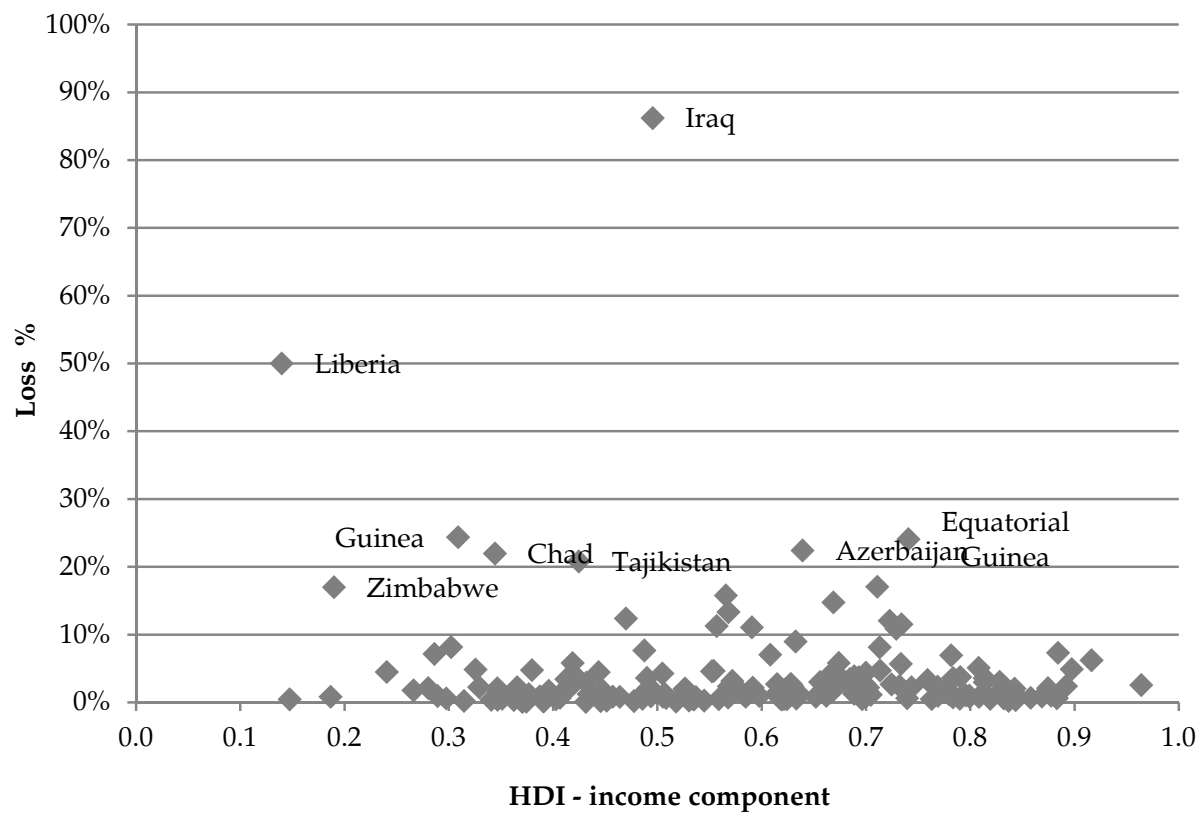

Uncertainty-adjusted HDI

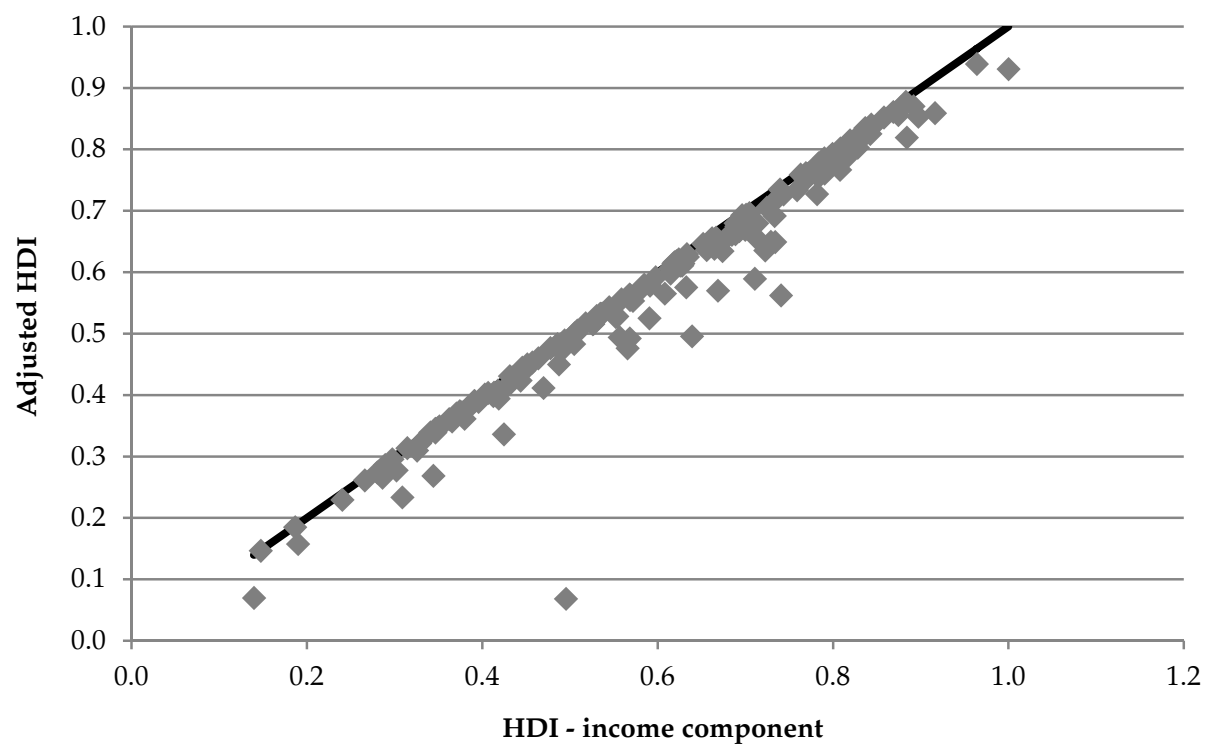




\section{Figure A3: GNI growth}

(annual percent)
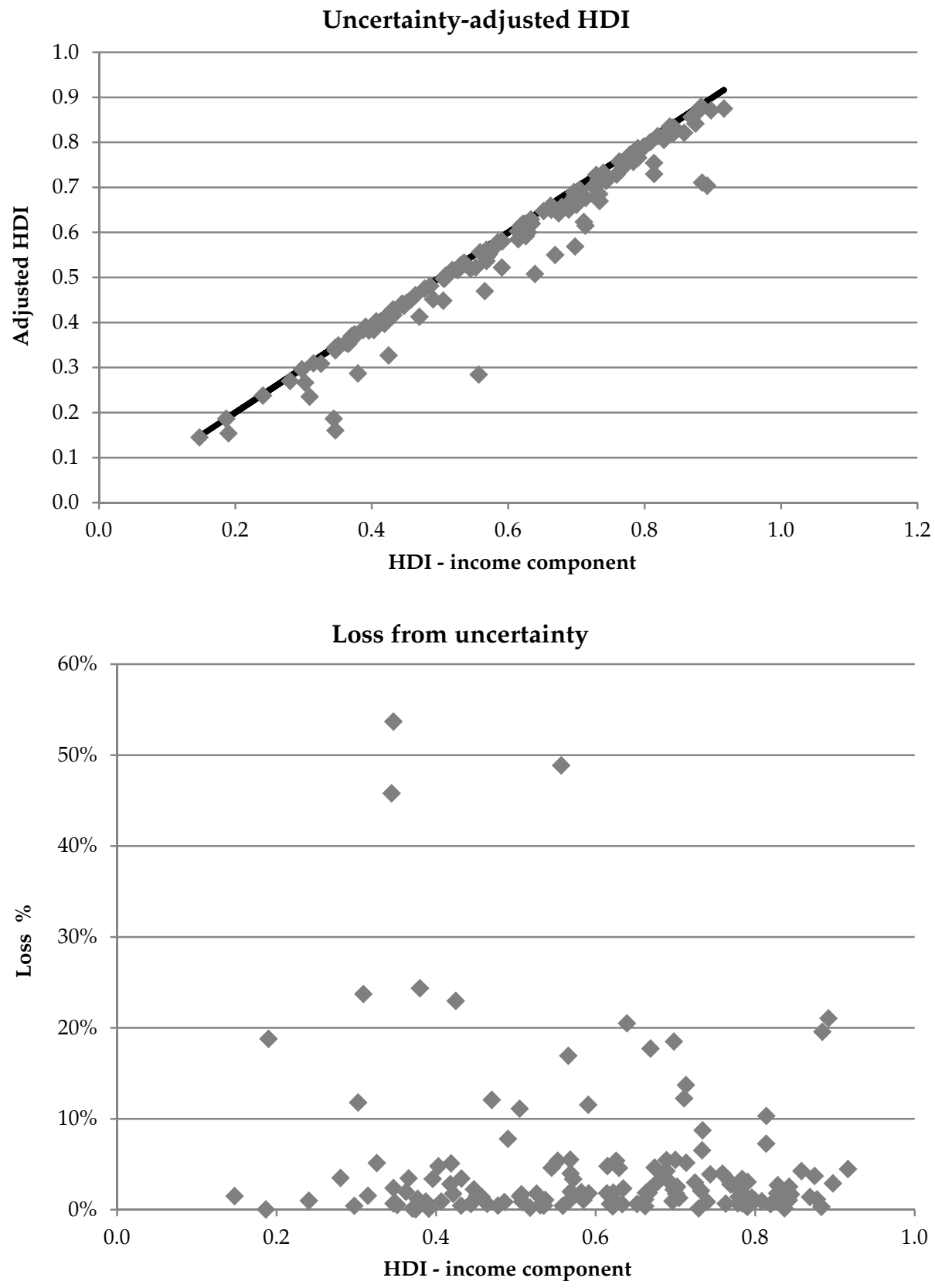
Figure A4: GNI per capita growth (annual percent)

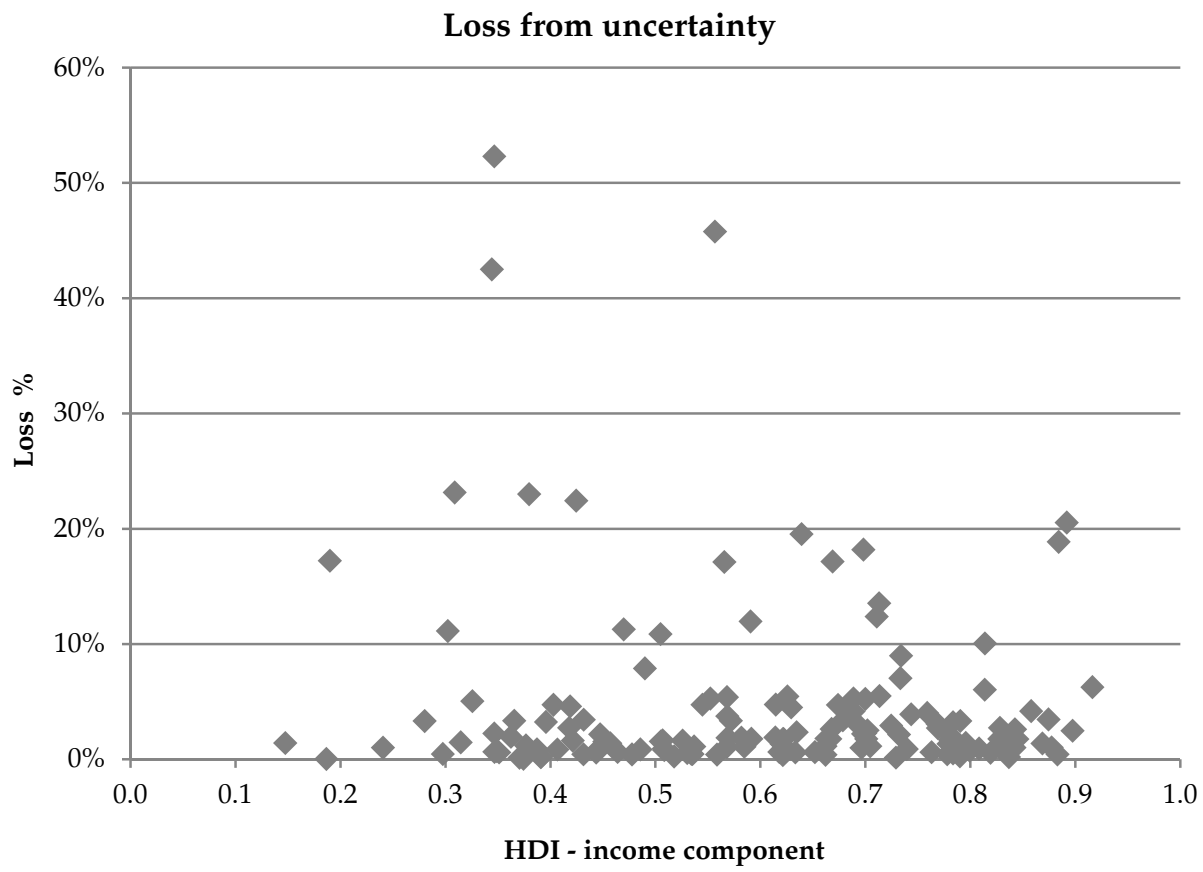

Uncertainty-adjusted HDI

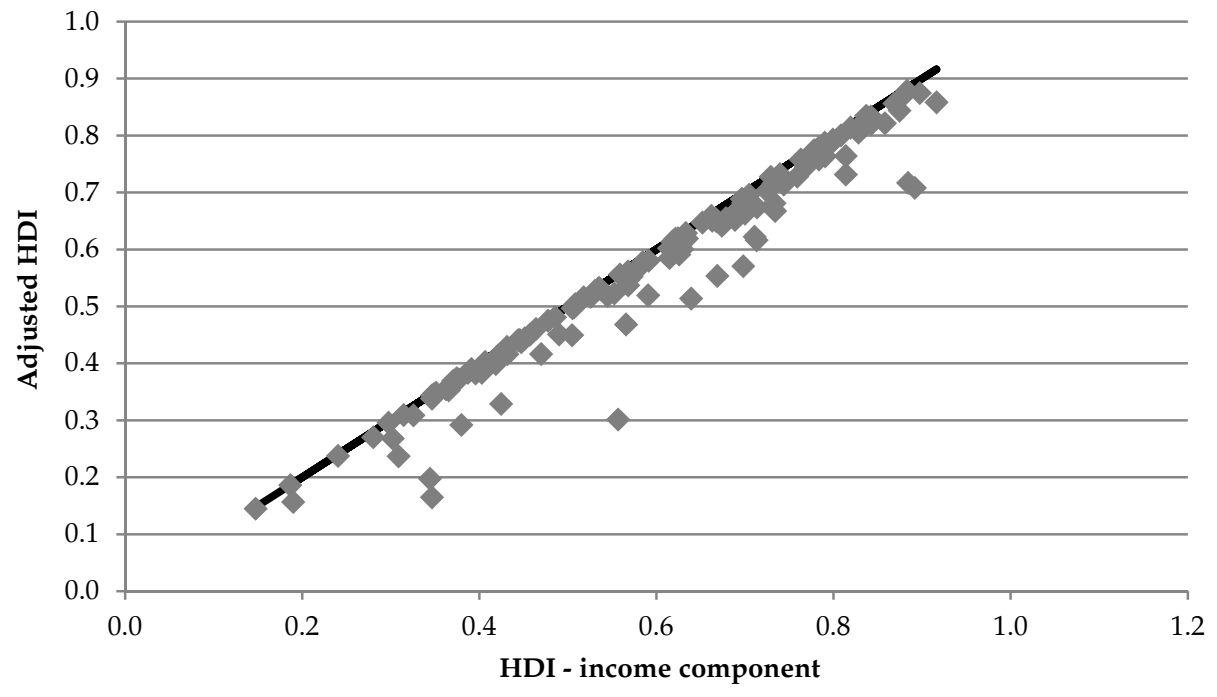


Figure A5: Household final consumption expenditure (annual percent growth)

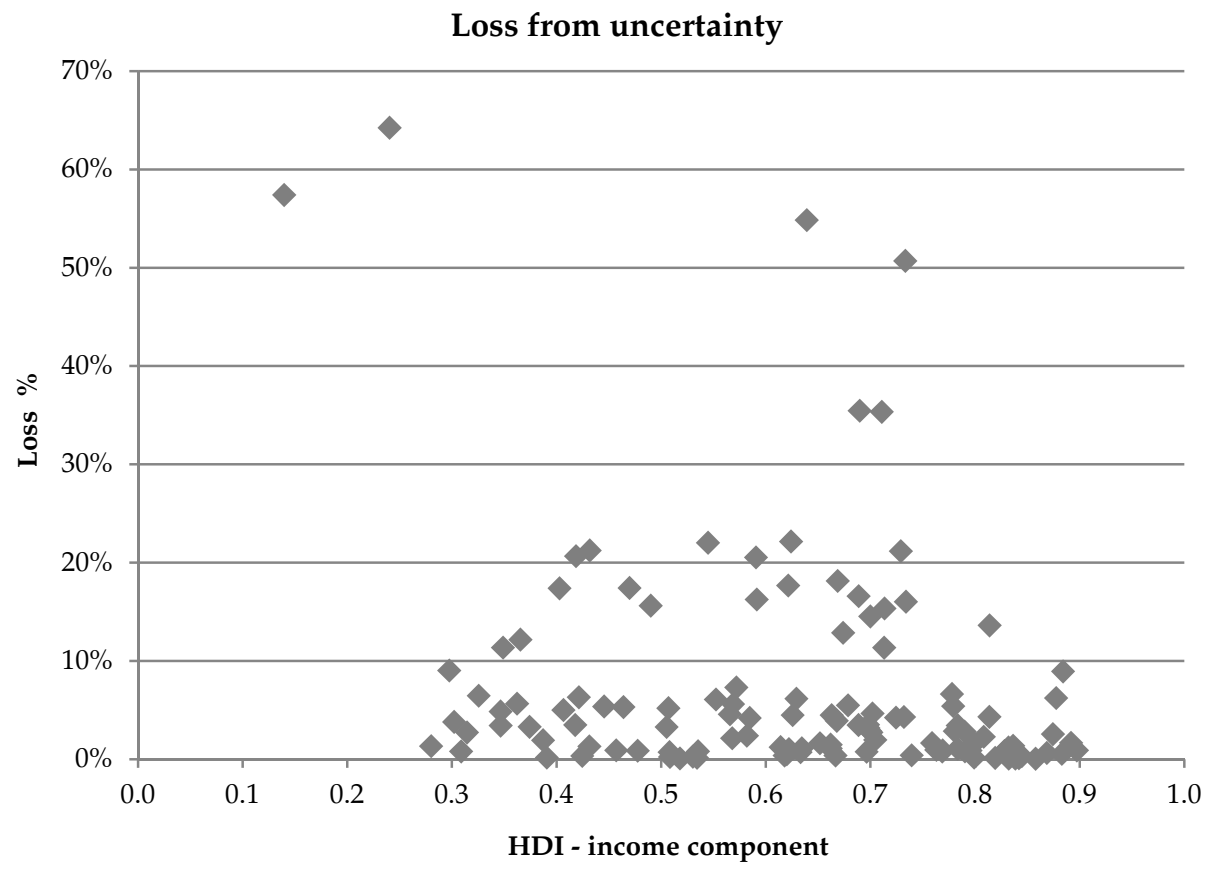

Uncertainty-adjusted HDI

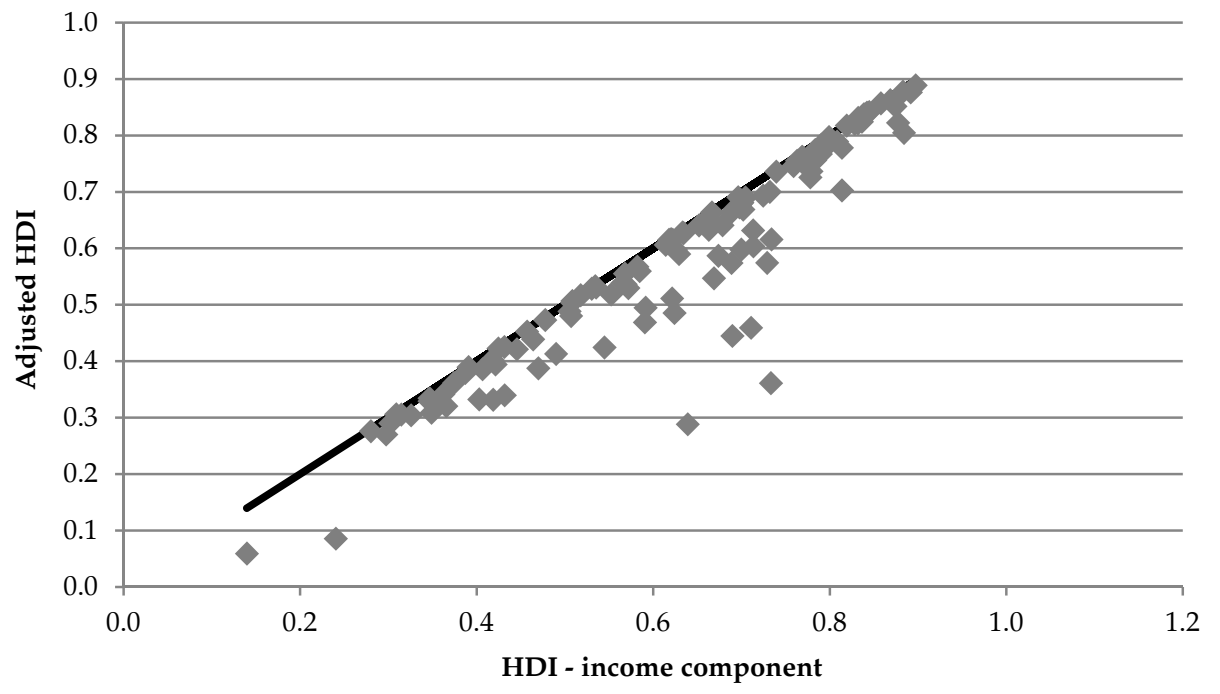


Figure A7: Household final consumption expenditure, etc. (annual percent growth)
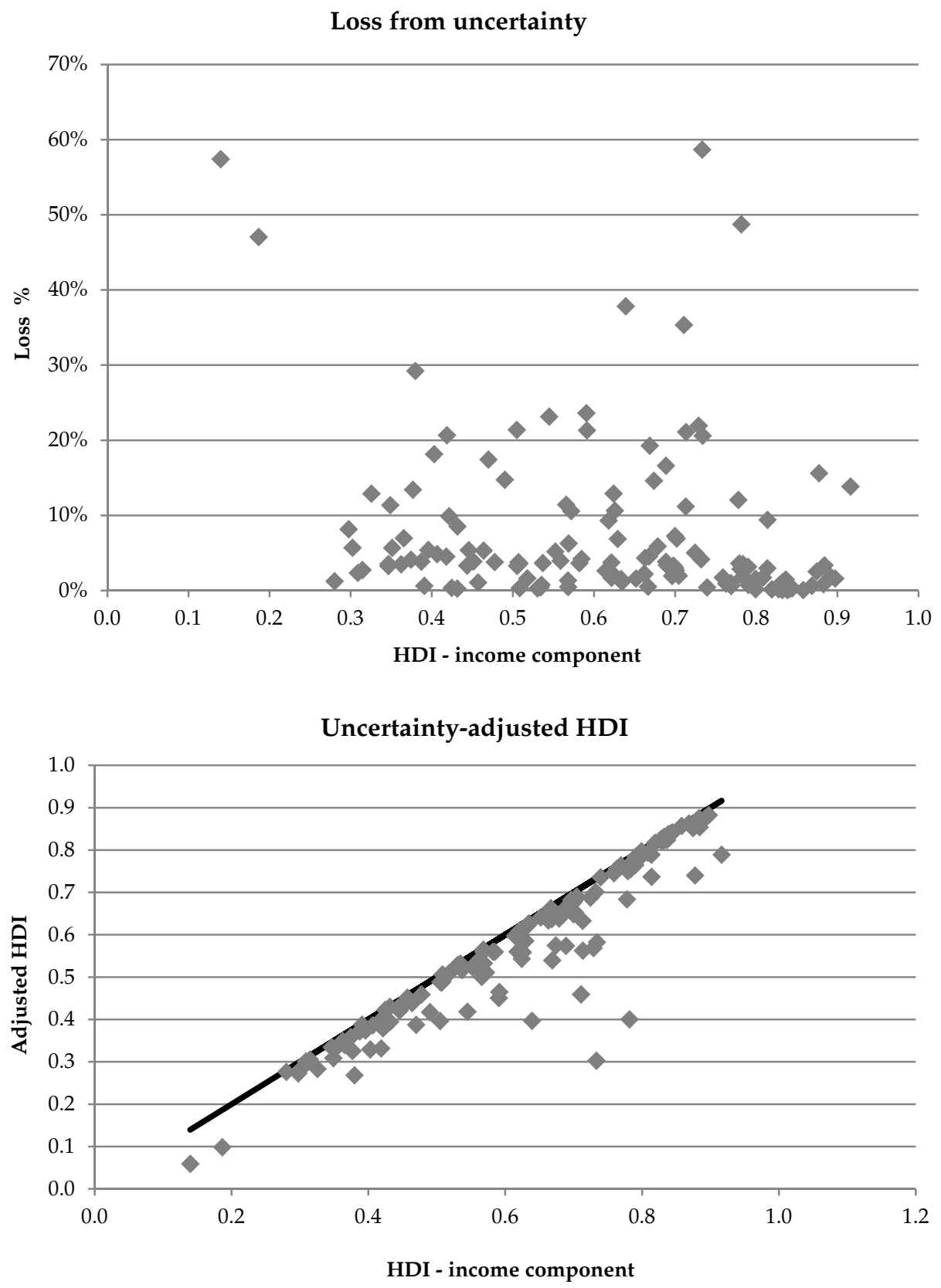